This is a pre-copyedited, author-produced version of an article accepted for publication International Journal of Law, Policy and the Family, following peer review. The details of the version of record are as follows International Journal of Law, Policy and the Family, Volume 33, Issue 2, August 2019, Pages 252-275, https://doi.org/10.1093/lawfam/ebz006.

Accepted version downloaded from SOAS Research Online: http://eprints.soas.ac.uk/31847

\title{
THE IMPACT OF THE CONVENTION ON THE ELIMINATION OF ALL FORMS OF DISCRIMINATION AGAINST WOMEN IN SELECT AFRICAN STATES
}

\author{
Fareda Banda*
}

*Professor, Department of Law, University of London, School of Oriental and African Studies

\begin{abstract}
While the UN Convention on the Elimination of all Forms of Discrimination against Women (CEDAW) is seen to be an African success story, in order to obtain some sense of the impact of CEDAW in African legal systems, this article considers cases in which CEDAW provisions on the family have been invoked in those jurisdictions and provides a snapshot of key issues identified by the Committee in the case law, including changes in Constitutions. This is set in the context of the challenges of applying international standards to local contexts.
\end{abstract}

\section{INTRODUCTION}

The UN Convention on the Elimination of all Forms of Discrimination against Women (CEDAW) seems to be an African success story. ${ }^{1}$ Out of 54 States, only two, Somalia and Sudan, have failed to sign or ratify the Convention. Advocates in African states have embraced the Convention and used it to hold states accountable for its implementation. They have brought test cases using the Convention to advance women's legal claims. The judiciary has been largely receptive to these claims. In most cases, African leaders and governments have been open to the lobbying efforts of civil society, and have sought to honour, normatively, if not always rhetorically, the pledges that they have made by ratifying CEDAW and other human rights instruments, but also in their participation of the Universal Peer Review process and at international conferences such as Beijing in 1995 and beyond. African governments have pointed to their ratification of CEDAW as proof of their commitment to human rights in general and women's rights in particular. ${ }^{2}$ This has played 
well with international aid donors some of whom require a commitment to gender equality as a precondition to engagement.

The Millennium Development Declaration and Goals, since supplemented by the Sustainable Development Goals, have acted as a further impetus to action by putting, as they both do, gender equality at the centre of development initiatives. ${ }^{3}$ Reinforcing all this has been the development and strengthening of regional and sub-regional human rights initiatives, not least the adoption of the Protocol to the African Charter on Human and Peoples' Rights on the Rights of African Women, 2003 (the Maputo Protocol or the African Women's Protocol). ${ }^{4}$ The Protocol has been ratified by 40 States. ${ }^{5}$

It is self-evident that much of the discrimination experienced by women on the African continent arises from discriminatory family laws. ${ }^{6}$ The issues covered in article 16 of CEDAW, equality in entry to and exit from marriage, equal distribution of property on divorce (and death) and the same rights and responsibilities with regard to children, along with a prohibition of forced and early marriage, are consistently flagged up as problematic for women. However, in concluding its dialogue with Senegal, the CEDAW Committee remarked on the 'lack of cases in which discrimination has been invoked, showing the limited efficiency of the formal appeal mechanisms. ${ }^{77}$ In this article, in order to obtain some sense of the impact of CEDAW in African legal systems, I consider cases in which CEDAW provisions on the family have been invoked. ${ }^{8} \mathrm{I}$ also attempt to provide a snapshot of key issues identified by the Committee in the case law, including changes in Constitutions. ${ }^{9}$ But first it is necessary to consider the challenges of applying international standards to local contexts.

\section{CHANGING LAWS: CHANGING PEOPLE?}

Writing about women's rights, Feryal Cherif (2015: 9) acknowledges the difficulties of considering explanations for regression or advancement of human rights in isolation because doing so 'often leads to multiple and sometimes conflicting conclusions about which accounts best explain change. ${ }^{10}$ She is not alone. Andrew Byrnes and Marsha Freeman (2012) identify the challenges of making a causal connection between ratification of CEDAW and legal changes made in a specific context. ${ }^{11}$ There has been a marked increase in literature querying the claims made for and about the efficacy of human rights. ${ }^{12}$ It is a telling indictment of lawyers that most of the literature on the efficacy of law in changing attitudes 
and behaviour comes from political scientists, sociologists, legal anthropologists and, occasionally philosophers. ${ }^{13}$

Legal anthropologist, Engle Merry (2017), refers to a process of vernacularisation which involves making norms locally relevant. Catharine Mackinnon (2017) uses Lorenz's 'butterfly effect' (the effect of one action - the flapping of a butterfly's wings in Brazil, on another event, the setting off of a tornado in Texas) to reflect on how her forty years of advocacy for women's rights has led to many changes in law and culture. These include accepting that sexual harassment constitutes a form of violence and that the ratification of human rights instruments has a positive effect on state behaviour because it forces them to behave better and gives citizens the tools to ensure that this happens. ${ }^{14}$ To this Ryan Goodman and Derek Jinks (2013) add emulation, or the desire of states to be seen to be in step with other states and with international consensus. It is a positive example of "peer pressure' at work. ${ }^{15}$

Abdullahi An Na'im NEED REFERENCE puts forward a methodology for reconciling international human rights with local viewpoints. This calls for internal discourse at the local level during which all members of the community/communities work together to ascertain their values. This process is then followed by cross-cultural dialogue with the international system. The goal is to create cultural legitimacy for human rights and in that way to obtain local 'buy in'. In many ways this is the work that many local Non-Government Organisations do with variable rates of success. ${ }^{16}$ The African Protocol, in article 17 is insistent on the importance of including women in the framing of positive cultural values while in its joint General Recommendation with the Children's Rights Committee, the CEDAW Committee stated:

'The Committees recommend that the States parties to the Conventions ensure that any efforts undertaken to tackle harmful practices and to challenge and change underlying social norms are holistic, community based and founded on a rights-based approach that includes the active participation of all relevant stakeholders, especially women and girls'. ${ }^{17}$

There has been a rise in the use of indicators to trace progress made. The problems of using indicators as measures of progress are well documented (see Engle-Merry, Davies and

Kingsbury, 2015; Engle-Merry, 2016) . These include the use of different methodologies and data sets to collate the findings. There is also the problem, identified in the Mid-Term Review of the African Women's Decade, of the variability and availability of reliable data sets. It relies on the World Economic Forum Gender Gap Index 2015 for its data. In so doing it 
identifies that 34 out of 54 African countries are included in the Index out of 148 countries. $^{18}$

There are 193 States within the UN family. Where are the data for the others? In his analyses of the uses and misuses of development statistics, Morten Jerven (2013) queries the efficacy of demanding 'evidence based policy' when the statistical evidence on which policies are made is itself incomplete, invented, out of date and flawed. Despite these shortcomings, it is still worth acknowledging that reports on gender equality produced by institutions such as the World Bank have enormous impact. The Nigerian representative told the CEDAW Committee:

'The review of family law currently under way took as its basis a comprehensive study, sponsored by the World Bank and the United Nations Children's Fund (UNICEF), designed to identify all discriminatory provisions in the relevant legislation at all levels.' ${ }^{19}$

Another consideration is the status of international instruments in local law. In practice, it does not seem to matter whether a state is a monist or dualist one, that is, whether ratification leads to direct implementation, or whether incorporation into the national law is required before the Convention can take effect. Sometimes states move between the two or have a hybrid model. In its 2017 dialogue with the Rwandan delegation, CEDAW was told that the Convention could be invoked and applied directly in national courts. However, the Committee also learned that an amendment to its 2015 Constitution meant that 'the Constitution and organic laws take precedence over international treaties'. In its concluding observations, the Committee indicated a preference for the position that pertained prior to the constitutional change where international treaties took precedence over the constitution and organic laws. ${ }^{20}$ Concluding its examination of Niger in July 2017, the Committee noted that, while article 171 of the Constitution gave precedence to ratified international treaties over national legislation, still:

‘... Act No. 62-11 of 16 March 1962 and Act No. 2004-50 of 22 July 2004 give precedence to the application of customary law over civil law in most personal status matters, including marriage, divorce, direct descent, inheritance, settlement of assets and wills and in relation to property ownership, adversely affecting women and girls." 21

However, an examination of case law shows that, in dualist states, many judges are willing to overlook the non-incorporation of a Convention into domestic law. They regard the State's ratification as a manifestation of a commitment to honour obligations undertaken at the international level (pacta sunt servanda). ${ }^{22}$

III. ON 'UNIVERSALITY' 
The implementation and prioritization of international norms at the domestic level poses a particular challenge with respect to family law. The main difficulty for all states around the world is respecting article 27 of the Vienna Convention on the Law of Treaties 1969 which provides in part: 'A party may not invoke the provisions of its internal law as justification for its failure to perform a treaty.' All regions have developed some 'mediatory' interpretive tools in their attempts to reconcile the local with the global. For Europe, this comes in the form of the doctrine of the margin of appreciation; for Asia, politicians claim 'Asian values'; African leaders talk of 'African cultures and traditions' while article 43 of the Arab Charter proffers its own, hard to square, solution of interpreting human rights through the prism of both international and domestic law. ${ }^{23}$

Pluralism in family formation and construction was anticipated from the very beginning of the United Nations. Johannes Morsink's account of the drafting of article 16 (on family) of the Universal Declaration of Human Rights, shows clearly that States were agreed that individual States should be left to decide on form and formalities of personal status laws (Morsink, 2000: ch. 7). The provisos were that that there should be consent of both parties to marriage and that they should be of marriageable age. Equality was also a cornerstone. This interpretation has cascaded down the UN human rights system. CEDAW General Recommendation 21 on Family notes:

'The form and concept of the family can vary from State to State, and even between regions within a State. Whatever form it takes, and whatever the legal system, religion, custom or tradition within the country, the treatment of women in the family both at law and in private must accord with the principles of equality and justice for all people, as article 2 of the Convention requires'. ${ }^{24}$

It is worth noting that in almost all systems the equality principle seems to apply to heterosexual marriages. States appear to have some leeway in the recognition that they give to LGBTI unions (see further Banda and Eekelaar, 2017). CEDAW addressed same-sex marriages in its General Recommendation No.29 where it acknowledged that not all States recognize same-sex marriages or partnerships:

'Certain forms of relationships (i.e. same-sex relationships) are not legally, socially or culturally accepted in a considerable number of States parties. However, where they are recognized, whether as a de facto union, registered partnership or marriage, the State party should ensure protection of economic rights of the women in these relationships'.

On the African continent, South Africa, whose constitution guarantees freedom from discrimination on grounds of sexual orientation, recognizes same-sex marriages. The Civil Union Act accords identical marriage rights to those in same-sex unions as those in 
heterosexual ones. ${ }^{25}$ By way of contrast, the constitutions of both Kenya and Zimbabwe follow the drafting in the Arab Charter and explicitly exclude the inclusion of same-sex relationships by defining marriage in heterosexual terms. ${ }^{26}$ Similarly, the Nigerian legislature has passed a law prohibiting same-sex marriage. ${ }^{27} \mathrm{An}$ attempt to challenge it has been unsuccessful (see Chinwuba Onuoru-Oguno, 2017: 238 ). In other African states, the criminalization of homosexuality puts paid to any idea of people marrying someone of the same sex. If anything, a report by the Human Dignity Trust points to lesbian women being pressured into marriage with men, as a 'cure' for or to hide their sexual orientation (Human Dignity Trust, 2016).

\section{EQUALITY V. EQUITY}

Equality is considered to be jus cogens, or peremptory norm. ${ }^{28} \mathrm{UN}$ human rights instruments and jurisprudence speak to the importance of substantive equality whereby states ensure that their laws do not contain discriminatory provisions, whilst also ensuring that everyone in the society has the possibility to enjoy the rights in practice. ${ }^{29}$ This view of equality has been reinforced in regional systems, notably the Inter-American and African. ${ }^{30}$ However, this is not universal. The Arab Charter, 2004 contains the standard non-discrimination and equality before the law provisions but then also provides in article 3(3):

'Men and women are equal in respect of human dignity, rights and obligations within the framework of positive discrimination established in favour of women by the Islamic Shariah, other divine laws and by applicable laws and legal instruments. Accordingly, each State party pledges to take all the requisite measures to guarantee equal opportunities and effective equality between men and women in the enjoyment of all the rights set out in this Charter.'

There are States on the African continent which are States parties to CEDAW, the African Charter and also the Arab Charter. When it comes to family law, which model of equality are they applying? Is it the first sentence in article 3(3) of the Arab Charter, which echoes the Cairo Declaration on Human Rights in Islam ${ }^{31}$ with its religious framing of rights and its insistence on a complementarity model of equality or equity; or is it the second sentence whose demand that states guarantee equal opportunities and effective equality, mirrors CEDAW General Recommendation No. 25 and its demand for substantive equality? ${ }^{32}$ It is singularly unhelpful that the Arab Charter cites both the Cairo Declaration as well as the International Bill of Rights (which consists of the Universal Declaration of Human Rights (UDHR), the International Covenant on Civil and Political Rights (ICCPR) and the International Covenant on Economic, Social and Cultural Rights (ICESCR)) as the inspiration for its drafting in the preamble. Significantly it omits CEDAW. In its report to 
CEDAW, Saudi Arabia acknowledged that there were interpretive differences with respect to equality and the roles of men and women:

'The Islamic Shariah respects these natural differences and accords women a privileged position in order to achieve justice for her. For example, it charges the man with earning a living to provide for himself and his wife as compensation for the woman's role as conceiver, child bearer and mother.' 33

This regional variation also matters because of a potential clash of norms. The Arab Charter is an instrument of the Arab League which has nine African states as members (Algeria, Djibouti, Egypt, Libya, Mauritania, Morocco, Somalia, Sudan, Tunisia,) all of which have ratified the African Charter and five of which have also ratified CEDAW, some with reservations, others not. Egypt is the only Arab League State to have reservations to the equality provisions of the African Charter. ${ }^{34}$ Only three States have ratified the African Women's Protocol: Djibouti, Libya and Mauritania. ${ }^{35}$ This normative pick and mix creates uncertainty and leaves women open to discrimination. ${ }^{36}$ It is for this reason that CEDAW is insistent on equal rights between men and women (see Facio and Morgan, 2009).

As many jurisdictions have plural legal systems, we also need to unpack the idea of equality. Equality with whom? Equality between men and women generally, or equality between men and women in the operation of one of the plural normative orders, or equality between women regardless of which normative order is applying ${ }^{37}$ (for further discussion see Mujuzi, 2019).

The definitive (legal interpretation) answer to the equity v. equality question can be found in the African Commission case Egyptian Initiative for Personal Rights and Interights v. Egypt. Two human rights NGOs brought this case on behalf of four Egyptian women who had been arrested while protesting on the streets of Cairo. They were detained and mistreated while held by the authorities. The communication alleged many violations, including a breach of articles 2, 3 and 18(3) of the African Charter on discrimination and equality before the law. The complaint also cited CEDAW and the African Protocol, despite Egypt not having ratified or signed the latter. ${ }^{38}$ The African Commission upheld their communication. In making a finding of violations of articles 2, 3, and 18(3), the Commission used the definitions of equality found in CEDAW and the mirror provision in article 1(f) of the African Women's Protocol. ${ }^{39}$ In its analysis on gender based violence, the Commission relied on CEDAW General Recommendation No. 19 as well as case law from the Inter-American Commission, thus showing the cross-pollination of legal reasoning and the universalisation of the norm 
prohibiting gender based violence and indeed discrimination on grounds of sex and gender. ${ }^{40}$ The case also highlights the importance of civil society organisations in highlighting human rights violations against women. ${ }^{41}$ In October 2017, the court that oversees the West African sub-regional bloc, ECOWAS, also cited CEDAW, the ICCPR, the UDHR and the African Protocol on Women's Rights in its findings on a case on gender-based violence brought against Nigeria. ${ }^{42}$

As already noted, another point of difference between the two women's treaties includes the fact that the African Protocol allows polygyny but CEDAW does not. ${ }^{43}$ In her discussion of the approaches of the two treaties to the issue of polygyny, Celestine Nyamu-Musembi (2013) is critical of the CEDAW approach. Which outcome does justice to the woman: the one that denies polygyny in the interests of equality, ostensibly for women, but which has the effect of leaving a woman in a de facto polygynous union without remedy, or one that recognises her and provides protection?

\section{ON RESERVATIONS}

An examination of the CEDAW's engagement with African States suggests that the existence of plural legal systems with different laws and formalities for different groups poses a major problem in both the interpretation and implementation of the Convention. ${ }^{44}$ While reservations may breach what Rebecca Cook (1990) calls the integrity of the Convention, the States that have entered reservations have at least articulated the problem and made clear their difficulties in squaring the domestic laws with the international requirements. Moreover, as Jane Connors has noted, the many reservations to article 16 of CEDAW undermine the object and purpose of CEDAW which is the elimination of all forms of discrimination against women, and indeed of article 18(3) of the African Charter, which is the elimination of every discrimination against women (Connors, 2013a: 573-4) (emphasis added).

Religious reservations, framed as respect for plural communities' personal status laws, are also unlikely to be undone in politically fraught environments. In a 2017 report on the impact of fundamentalism, the UN Independent Expert on Culture noted that States were using their reservations to human rights instruments such as CEDAW to counter fundamentalists who tried to claim that the state had betrayed the religion. ${ }^{45}$ The entering and keeping of the reservations were used to show respect for the religion. Byrnes and Freeman (2012: 19) note how, despite maintaining a reservation to article 16, the Maldives had enacted a law that 
altered 'traditional Islamic rights and responsibilities between the spouses', and specifically property distribution on divorce. The authors observe that this may suggest 'considerably more flexibility than commonly seen in States in which Islamic law affects even part of the population' (Byrnes and Freeman, 2012: 20; see also Musawah, 2017). CEDAW uses the experience of States with similar religious leanings to encourage states to consider uplifting their reservations. ${ }^{46}$

It is also worth noting that, while most States do not enter reservations to CEDAW, this does not mean that they implement the full Convention either. ${ }^{47}$ Moreover, although the focus is often on Islam, other religions also wield influence. In deference to Christian religious sensibilities, Rwanda and Uganda have both refused to ratify the African Women's Protocol because of article 14 which has a limited right to abortion. Conversely, women's rights advocates in Zimbabwe invoked the Bible in their successful demand that the government legislate against domestic violence (see Christiansen,. 2009: 179, 183).

CEDAW has engaged States on reservations by way of General Recommendations, Statements and in dialogue, beseeching them to uplift the reservations. ${ }^{48}$ These initiatives have met with some success (Byrnes and Freeman, 2012: 10-12). Tunisia and Egypt have withdrawn reservations to article 9(2) which linked the nationality of children to their father only. However, Egypt has retained its reservation to article 16 in which it justifies unequal distribution of property on divorce by reference to the differing obligations placed on men and women by the Sharia. While CEDAW has highlighted the centrality of article 5 on stereotyping and emphasized to States their role in eradicating gender stereotypes, States such as Niger still retain reservations to key CEDAW provisions, for example:

'The Government of the Republic of the Niger declares that the provisions of article 2, paragraphs (d) and (f), article 5, paragraphs (a) and (b), article 15, paragraph 4, and article 16, paragraph 1 (c), (e) and (g), concerning family relations, cannot be applied immediately, as they are contrary to existing customs and practices which, by their nature, can be modified only with the passage of time and the evolution of society and cannot, therefore, be abolished by an act of authority'. ${ }^{49}$

The poor life chances experienced by women and girls in Niger, which include some of the highest rates in the world of early, indeed child, marriage and maternal mortality, speak to the importance of States taking article 5 seriously. Article 5, together with article 2(f) enjoining States to 'take all appropriate measures, including legislation, to modify or abolish existing laws, regulations, customs and practices which constitute discrimination against women' reinforces the fact that CEDAW is about both law and practice. Indeed, the UN Working 
Group on Laws and Practices that Discriminate against Women, in its report on the family, reinforces the view of CEDAW in this regard. ${ }^{50}$

The challenge, in a world that celebrates diversity, is how to respect differences while honouring the pledge of equality? John Eekelaar's concept of cultural voluntarism has much to commend it and has the added advantage of being in keeping with the Committee's often expressed view that neither religious interpretation, nor claims for cultural exceptionalism can be allowed to get in the way of the central focus of the Convention: equality between men and women.

'While it (cultural voluntarism) upholds the right of individuals to practise their culture, and should not attempt to undermine a culture though denigration or humiliation of its members, whether it supports a culture may depend on contingent judgements of its value: it need not consider all of them as being worth promoting or beyond criticism. It is legitimate (indeed important) for the state to encourage openness and toleration within the community, but that does not require it to sustain cultural practices into the future for no reason other than that people practise them today or defer to attempts by contemporaries to compel subsequent generations to act in the same way as they do' (Eekelaar, 2013:30) ${ }^{51}$

\section{CONSTITUTIONAL CHANGE}

In 1960, the British Prime Minister Harold MacMillan delivered what has become known as the 'winds of change' speech. It was an acknowledgement that decolonization was inevitable. Macmillan stated that the aim of the British government was to encourage the creation of a society which respects the rights of individuals - a society in which individual merit, and individual merit alone, is the criterion for a man's advancement, whether political or economic.' ${ }^{52}$ The political transition did come, but women were short-changed. The constitutions passed down during the transition from colonialism to independence privileged the preservation of customary law and religion with respect to family law. The Constitutions contained human rights bills with non-discrimination provisions, but these provisions did not apply to family law, thus making discrimination against most African women legal. ${ }^{53}$

It has taken time, but it is clear that the era of ring-fencing family laws from the nondiscrimination provisions are almost at an end. There has been a raft of Constitutional reform among CEDAW ratifying States seeking to uphold CEDAW article 2(a) which requires States to ensure that their Constitutions are Convention compliant. Most Anglophone African States now have Constitutions that uphold equality for all before the law and that no longer privilege custom. ${ }^{54}$ The Committee regularly commends States which have compliant 
Constitutions. However, it usually goes on to identify the gap between having a supreme law that requires that there not be discrimination on grounds of sex and national laws, including family laws, that still retain discriminatory provisions. ${ }^{55}$ It is also noteworthy that, whatever the Constitutional arrangements, the Committee always comments on the gap between norms, the de jure position, and practice, the de facto position. ${ }^{56}$ In so doing, the Committee reinforces the interconnectedness of article 16 to other Convention provisions, not least articles 2(f) on modifying or abolishing discriminatory customs and practices, 5 (a) on gender stereotyping, 14 (2) (g) on land and 15 (1) on equality before the law. ${ }^{57}$

It is also worth noting that some Constitutions in Federal States devolve legislative power, meaning that there is a real problem in getting the provisions of domesticated international instruments through to State level because of the distribution of powers in the constitution (Chinyere, Millicent and Elizabeth, 2018).

\section{DOMESTIC CASE LAW}

\section{Zimbabwe}

The Zimbabwean case of Mudzuru and Tsopodzi v. Ministers of Justice and Women's Affairs $^{58}$ yielded a human rights rich analysis on child marriage and specifically the setting of different ages of marriage for boys and girls. Two female litigants brought a Public Interest challenge, arguing that section 22(1) of the Marriage Act, which permitted girls to marry at 16 if they had the consent of a parent or guardian (and boys at age 18) breached section 78(1) of the Zimbabwean Constitution: 'Every person who has attained the age of eighteen years has the right to found a family.' They also challenged the Customary Marriages Act for failing to specify a minimum age of marriage at all. ${ }^{59}$

The State argued that, as one could found a family without being married, age was irrelevant. The applicant's lawyers pointed out that a person under 18 could not marry and therefore could not consent to found a family. ${ }^{60}$ The applicant's lawyers also disputed the State's case that sought to justify different ages of marriage for men and women because girls mature faster, arguing that this constituted discrimination on grounds of sex and gender in breach of section 56 of the Constitution, as well as stereotyping. ${ }^{61}$ The constitutional prohibition on marrying under the age of 18 applied to both males and females. The applicant's lawyers elaborated on stereotyping, noting that it had the effect of denying girls an education and exposing them to harmful practices. In the last section of their submission, the applicants' lawyers turned to section 46 of the Constitution which required the State to honour its 
international obligations. ${ }^{62}$ They cited CEDAW article16(1) (c) (d) and (f). They also invoked article 2(c) of precursor to CEDAW, the Declaration on the Elimination of all Forms of Discrimination against Women, 1967. ${ }^{63}$

The judgment, which found for the applicant, provided a detailed analysis of the developments on human rights law on early and child marriage. ${ }^{64}$ Article 16(2) of CEDAW which prohibits child marriage was analysed. It was noted that it did not actually set a minimum age of marriage. However, the Court referred to the Children's Rights Convention (CRC) noting: 65

'Although the CRC did not specify the age of eighteen as the minimum age for marriage, in defining "a child", it provided the CEDAW Committee and the CRC Committee with the basis for declaring the minimum age of marriage to be eighteen years. This is because Article 16(2) of the CEDAW provides in express terms that the "marriage of a child shall have no legal effect". 66

After exploring the gendered impact of child marriage on girls, the Court went on to cite article 21 of the African Charter on the Rights and Welfare of the Child 1990, which Zimbabwe had ratified (along with the other Conventions mentioned) and which expressly outlawed marriage before the age of 18 and enjoined States to protect girls from discriminatory customary practices. ${ }^{67}$ Returning to its analysis of the UN treaties, the Court cited statistics from the Children's Rights Committee on the prevalence of early marriage as well as the views of both the Human Rights Committee the Committee on Economic Social and Cultural Rights. The latter two Committees had recommended that the Zimbabwean government should equalize ages of marriage. ${ }^{68}$ The Court also quoted extensively from a UNICEF report on the negative consequences of early marriage. On CEDAW, the Court noted:

'The comment by the CEDAW Committee in General Recommendation 21 para. 38 was to the effect that provisions such as those of s 22(1) of the Marriage Act, which provided for different ages for marriage for girls and boys, assumed incorrectly that girls have a different rate of intellectual development from boys or that their stage of physical and intellectual development at marriage was immaterial. The Committee recommended that these provisions be abolished.'

The Court went on;

'The CEDAW Committee in making the comment in General Recommendation 21 para. 38 proceeded on the basis that it was common cause that the coming into effect of Article 1 of the CRC and Article 21 (2) of the ACRWC rendered provisions such as those contained in s 22(1) of the Marriage Act, and any other law authorising marriage of a person aged below eighteen years, inconsistent with the obligations of Zimbabwe under international human rights law to protect children against early marriage. The view held was that the abolition of 
the impugned statutory provisions would be consistent with the fulfilment by Zimbabwe of the obligations it undertook in terms of the relevant conventions and the Charter. The question was when the abolition would take place. ${ }^{69}$

Recalling article 18 on the Vienna Convention on the Law of Treaties 1969 to the effect that a State that ratifies a Convention must be seen to be willing to give effect to it, the Court noted that Zimbabwe was obliged to honour its clearly stated commitments. Furthermore, the Court noted that marriage was central to the foundation of a family and thus a child under the age of 18 could not found a family. Child marriage was prohibited regardless of the legal system in operation. It therefore ruled that section 22(1) of the Marriage Act was invalid as it violated section 78 of the Constitution.

This case is impressive because it shows what a court, well-versed in both human rights law and its application, can achieve. This in turn speaks to the importance of initiatives such as that run by the Commonwealth Secretariat to train judges. ${ }^{70}$ As the Unity Dow and Sarah Longwe cases $^{71}$ showed, sometimes women activists can bring their own experiences to bear in litigation which has the result of taking one person's story and bringing about change for an entire group.

Change may be due to many factors coming together. An example concerning early marriage has involved a coalition of civil society organisations such as PLAN and Girls Not Brides working with local agents, UN human rights Committees, UN agencies including UNICEF and the UN General Assembly. ${ }^{72}$ All have worked with and challenged governments to change their laws. ${ }^{73}$ They have been buttressed in this by courts. A news report noted that following the 2017 UN General Assembly meeting and resolution, the Presidents of Zambia, Uganda and Malawi all pledged their support to end child marriage by 2030. Malawi had already outlawed child marriage along with Chad, Gambia, Tanzania and Zimbabwe.

\section{Swaziland}

You know that you are in for a pro-woman judgement when a court prefaces its decision with the following words:

'This case is but the latest in a continuing series brought in many countries of the world by women in their attempts to redress what they claim to be discriminatory laws and practices which operated unfairly against women. These precepts and practices have deprived women of rights which were freely available to men, and kept women in a position of inferiority and inequality, in the various societies in which they live, work, pay their taxes, and raise their families, despite the fact that women contribute substantially to the growth and development of the communities and nations to which they belong. ${ }^{, 74}$ 
In this case, the Attorney-General was appealing a decision of the Swaziland High Court in its interpretation of the Deeds Registry Act. The case had been brought by a well-known women's rights activist, Doo Aphane. She had sought to jointly register a piece of land which she had bought with her husband to whom she was married in community of property. In Swaziland, a marriage in community of property bestows 'marital power' on the husband who is then considered responsible for administering property, including that of the wife. The couple had decided, on marriage, to keep their own surnames given at birth. The wife was told that the property could not be registered jointly in their respective names, or solely in her name. This was reflected in section 16(3) of the Deeds Registry Act and in the practice of the staff at the Deeds Registry:

'The immovable property had to be registered in the name of my husband as required by the aforesaid section and hence the Deeds Registry Office will not accept the registration of the property in our joint names. ${ }^{75}$

She went on to explain that, despite over twenty years of marriage and the use of their own names throughout the marriage, the practice of the Deeds Registry was to demand that the woman's name reflect that of the husband if both were to be registered. In a section entitled 'My Reaction', she says: 'I was appalled...' ${ }^{76}$ In addition to feeling affronted, Doo Aphane went on to note that the provision violated sections 20 and 28 of the Constitution of Swaziland, which guaranteed equality before the law and guarantee women equal treatment with men. ${ }^{77}$ This was accepted by the Attorney-General and the High Court gave judgment for Aphane. In so doing, the High Court noted that the offending section of the Deeds Registry should be read as amended to permit the joint registration (in different names) desired by the applicant. ${ }^{78}$

In bringing the appeal to the Supreme Court, the Attorney-General did not dispute the finding of discrimination, but rather argued that the High Court was not empowered to change the law by severing the offending provision and substituting words, this being the task of the legislature. Instead, the Court should have noted the Constitutional breach and given the government time to remedy it. ${ }^{79}$ The respondent pointed out that this solution left citizens at the mercy of the legislature. She also queried why, four years after the promulgation of a Constitution guaranteeing equality, 16 (3) of the Deeds Registry Act was still on the books. She further noted the inequity of expecting citizens to litigate to remedy every unconstitutional law. ${ }^{80}$ The Supreme Court confirmed the High Court's decision on the discrimination point, but substituted the part of the decision on the action to be taken by the 
government to remedy the breach. The Court declared section 16(3) to be invalid as it breached sections 20 and 28 of the Constitution on equality. ${ }^{81}$ The government was given twelve months to change the law. Doo Aphane could return to the court if this was not done. The Deeds Registry was to register properties in joint names. ${ }^{82}$

Commendable about the Supreme Court decision was its recognition that, although Aphane had brought the action in her personal capacity, the decision taken would benefit many women. Furthermore, the Court was also alive to the costs of litigation and considered that the State ought to pay the costs of the action in both the High Court and the Supreme Court. This is in important recognition of the access to justice barriers that face women and which prevent them from vindicating their rights. ${ }^{83}$ However, Cherif (2015: 166) is more circumspect in her analysis, noting that, while ratification of treaties may lead to gains for women in land rights, they do not necessarily translate into change with respect to discriminatory laws and in particular inheritance rights. She further notes that, ' $[T]$ here is little to no evidence that advocacy may ameliorate the inequalities in women's rights.' This speaks to a lack of social legitimacy. ${ }^{84}$ While giving Aphane due credit for bringing the action, Langwenya (2012) identifies continuing discrimination against women married in community of property. She argues that the judgment did not get rid of the concept of marital power, meaning that, even if women could now buy and register land in their own names, they would still need the consent of their husbands when seeking loans from the bank, indeed, even when seeking to use their land as collateral. While Swaziland was quick to link its ratification of CEDAW in 2004 with an overhaul of its Constitution in 2005, it has been slower to repeal or amend other discriminatory laws.

In its review of the combined first and second Swazi report to CEDAW, the Committee noted that, while the Constitution had been changed, the definition of discrimination in section 20 needed further elaboration to include discrimination on grounds of marital status.

Furthermore, the Committee identified the lack of progress in repealing discriminatory laws. Invoking the Aphane case the Committee expressed concern that: 'the amendment to the Deeds Registry Act of 2012 following the ruling of the High Court in Attorney General v. Mary-Joyce Doo Aphane has not been widely disseminated among women and is being poorly implemented. ${ }^{185}$ The Committee recommended that the State submit a post two-year review report on steps taken to disseminate the findings of the Aphane decision and also on actions taken to tackle violence against women. ${ }^{86}$ 


\section{Uganda}

The next national case was brought by a women's rights organisation, Mifumi, which worked in Uganda. ${ }^{87}$ It challenged the practice of bridewealth, a pre-marital token of esteem given by the family of the groom to the family of the bride. While still computed in livestock, it is now more often paid in cash. Mifumi argued that bridewealth magnified discrimination against women. It argued that women were compelled to stay in difficult marriages because of fear that if they left, their families would have to return the bridewealth. Moreover, Mifumi noted that bridewealth resulted in women experiencing violence at the hands of husbands who acted as if they were property. In support, Mifumi cited the CEDAW concluding observations to the report of Uganda in which the Committee had called for the abolition of bridewealth which, to the chagrin of both the Constitutional and Supreme Courts, it called bride price. ${ }^{88}$ Mifumi also noted that it breached the non-discrimination provisions of the Constitution ${ }^{89}$ and also those provisions that called for women to be protected from discriminatory customary practices. ${ }^{90}$ It recalled Uganda's ratification of CEDAW in 1985 and argued that there was an obligation under CEDAW article 2(f) to modify or abolish discriminatory practices. Mifumi also cited the African Women's Protocol obligation on States to protect women from practices that violate their dignity. ${ }^{91}$ Mifumi argued that the requirement to return bridewealth before a divorce lowered the dignity of women, violating Articles 31(1)(b), 32(2) ${ }^{92}$ and 33(1) of the Constitution.

The Constitutional Court refused to hold that bridewealth was discriminatory or that it led directly to violence against women. The court pointed out that there was violence in countries which did not have the bridewealth practice. It emphasized that the giving of bridewealth was a voluntary arrangement between families which was popular. It did however find that the requirement for a return of bridewealth as condition of divorce did lead to women being forced to stay in unhappy marriages. The court agreed with Mifumi that the refund requirement undermined women's dignity and violated their equal rights with men in their rights to enter marriage, during marriage and in the dissolution of marriage in breach of Articles 31(1) and 33 of the Constitution.

Mifumi appealed the decision to the Supreme Court which confirmed the decision of the Constitutional Court. The practice of giving gifts at marriage did not constrain women's ability to enter marriage, nor did it constitute discrimination against them. However, it did note that the Constitutional Court should have made a declaration of unconstitutionality with 
regard to the demand for refund of bridewealth as a condition precedent to divorce. A dissenting opinion, which cited CEDAW articles 2(f), 16 (1) (b) and 16 (1) (c), found for Mifumi. Justice Esakaye noted that there was little choice for women but to agree to the bridewealth arrangements entered into by their families as a precursor to finalising a customary marriage. Perceptively the judge noted the pressures that were brought to bear on women to enter into marriage on terms dictated to them by their families. They did not enjoy the freedom to enter into marriage as anticipated in article 33 of the Constitution and as enshrined in both CEDAW article 16 and the African Protocol. She linked this to discrimination and found for Mifumi on all points. Chuma Himonga (2017) agrees with the majority in this case, arguing that there are some customs, including bridewealth, which she calls lobolo, which have cultural legitimacy, including with women. These practices should be respected. Clearly, she understands the acceptance of the practice as not causing harm to most participants. In a 2012 report on women and culture, the UN Special Rapporteur in the Field of Cultural Rights was clear that, while equality remained an inviolable norm, culture should not be denigrated as always exploitative of, or harmful to, women. ${ }^{93}$ It may well be that CEDAW will need to focus as much on the modifying part of article 2(f) of the Convention and less on a unilateral demand of abolition of practices which it may not always understand, but which women in the affected communities may support.

\section{CEDAW AND THE OPTIONAL PROTOCOL}

The number of African states that have ratified the Optional Protocol to CEDAW 1999 is small, but growing. ${ }^{94}$ The Optional Protocol is an addendum to the Convention. It allows for individuals or groups of individuals to bring complaints about violations of CEDAW by the State. It is necessary first to exhaust domestic remedies before sending a communication to the Committee. There is also provision for an Inquiry process which allows the Committee to investigate serious or grave violations of rights that are systematic. The Committee issues findings and recommendations at the end of its consideration of a communication or at the end of the inquiry process. (See Connors, 2013). The use of the Optional Protocol has been slowly rising. However, knowledge of the Optional Protocol is not as widespread as of the Convention itself. Its use is also constrained by the preference of national NGOs to develop and strengthen, by use, the regional system. It is for this reason that organisations such as Equality Now and the Initiative on Strategic Litigation, amongst others, work with local 
lawyers to find test cases to bring before the African Commission. There has been a case involving African women brought to CEDAW using the Optional Protocol.

ES and SC v. Tanzania ${ }^{95}$ was brought by two widows who had successfully challenged the discriminatory customary law of inheritance that precluded them from either inheriting from, or indeed even administering, the estates of their deceased husbands. While agreeing that the provisions of the Local Customary Law (Declaration) (No. 4) Order violated the Constitutional provisions that guaranteed equality before the law, the Court had refused to declare the customary law invalid on the basis that it could not unilaterally change customary law from the Bench. Their appeal was unreasonably delayed so the widows brought a claim to CEDAW alleging violations of articles 2 (c) and 2 (f) (equal protection through competent tribunals and also the abolition or modification of problematic customs and practices), 5(a) on stereotyping, 13 (on access to mortgages and economic benefits), 15(1) and (2) on equality before the law and 16 (1) (c) and 16 (1) (h) read together with CEDAW General Recommendations No. 21 o (b) family and 27 on older women. ${ }^{96}$

Upholding their claim on all counts, CEDAW found that the women had indeed been discriminated against as they alleged. ${ }^{97}$ It noted the disadvantages experienced by these women, including their exclusion from participating in economic activity as well as the gender stereotyping at play. In addition to making a finding of all the violations claimed, the Committee added to the General Recommendations, General Recommendation No. 29 on property distribution and referred specifically to the paragraph directing States to prohibit the disinheritance of widows. ${ }^{98}$ The Committee recommended that the women be compensated and also asked the State to ensure compliance between national laws and the Constitutional and Convention requirements for equality between men and women. Having been criticized for its condemnatory approach to custom and culture, the Committee also displayed sensitivity, recommending that the State:

(v) "Encourage dialogue by holding consultations between civil society and women's organizations and local authorities, including with traditional leaders at the district level, with a view to fostering dialogue on the removal of discriminatory customary law provisions." 99

The Committee also recognised the importance of educating not only judges in all levels of courts about the Convention and the Committee's General Recommendations, but also women, especially those in rural communities about their rights. ${ }^{100}$ 
This case will be particularly helpful in the articulation of property entitlements and equality of women under the Sustainable Development Goals. It is noteworthy that both women had contributed to the acquisition of the family property that they were being denied by relatives who had not contributed anything but merely relied on a perversion of custom to seek to unjustly enrich themselves. Returning to the social change literature discussed in the first part of this chapter, one can see clearly the role played by the interveners who were able to bring the case on behalf of the women. ${ }^{101}$ Without them translating the women's problems into violations ripe for remedy by CEDAW, the women would have been without a remedy (see Byrnes and Connors, 1996).

There is a footnote to this case. In its consideration of the report of Tanzania in 2016, the CEDAW Committee noted its disappointment that the State had failed to implement the Committee's findings in the ES case. The State also failed to provide information on what had been done to address the views of the Committee. ${ }^{102}$ The Committee reiterated the importance of repealing or amending discriminatory laws, including the Customary Declaration which had been the challenge in the ES case. The Committee also reminded the State of its duty to provide education for both populace and office holders in order to transform attitudes. ${ }^{103}$

Not wishing to end on a sour note, it is worth noting that, presenting its report to CEDAW, the Rwandan representative noted that, to make it more accessible, CEDAW had been translated into Kinyarwanda. ${ }^{104}$ Crucially, she noted that men had begun to see and support the benefits of women's empowerment. ${ }^{105}$ Separately, CEDAW commended Sierra Leone for its efforts to regulate customary marriage and inheritance but noted that there was a lack of institutional capacity in the Ministry responsible for overseeing gender. ${ }^{106}$

\section{CONCLUSION}

This article has tried to provide a snapshot of CEDAW in the African context. It began by looking at literature on the impact of the ratification of human rights treaties on law reform and societal practice. Consideration was also given to the challenges of implementing family policy in States with plural legal systems which led to the question: can there be a universal understanding of equality? An examination and short comparison of the international and regional human rights systems suggests that there is not a definitive answer. The only clear point is that in all societies, social attitudes continue to impact negatively on women's 
enjoyment of their CEDAW rights, especially in the family. It is however true that the Convention is used for legal education and advocacy purposes by civil society and increasingly relied upon in court judgments. Nevertheless, government-led implementation of the Convention's principles remains uneven at best, and poor at worst. This in turn makes it difficult to assess the efficacy of the Convention. The constitutional reform processes that have taken place, followed by some statutory law reform, gives some indication of the impact of CEDAW. Many States will continue to need assistance from civil society. Inter-state cooperation will involve 'peer pressure' to do better and also practical help. Importantly, States will have to ensure that the beneficiaries, the women, are well versed in their rights, and that those responsible for ensuring their implementation are both committed to, and up to, the task at hand.

\section{REFERENCES}

Appiah, A. (2010) The Honour Code: How Moral Revolutions Happen, New York: W.W. Norton and Co.

Banda, F. (2014) 'Changing the Constitution and Challenging Attitudes: Recent Developments in Kenyan Family Law' in B. Atkin (ed) International Survey of Family law 2014 255-73.

Banda, F. and Eekelaar, J. (2017) 'International Conceptions of Family' International \& Comparative Law Quarterly 66, 833-62..

Bond, J. (2014) 'CEDAW in Sub-Saharan Africa: Lessons in Implementation', Mich. St. L. Rev. 241).

Byrnes, A. et al (eds) (1994) Advancing the Human Rights of Women: Using International Human Rights Standards in Domestic Litigation, London: Commonwealth Secretariat.

Byrnes, A. and Connors, J. (1996) 'Enforcing the Human Rights of Women: A Complaints Procedure for the Women's Convention? Draft Optional Protocol to the Convention on the Elimination of all Forms of Discrimination against Women' Brooklyn Journal of International Law 21, 679-797. 
Byrnes, A. and Freeman, M. (2012) The Impact of the CEDAW Convention: Paths to Equality (February 20, 2012). UNSW Law Research Paper No. 2012-7. Available at SSRN: https://ssrn.com/abstract=2011655 or http://dx.doi.org/10.2139/ssrn.2011655 at.2-4, 12-14

Chanock, M. (2002) 'Human Rights and Cultural Branding: Who Speaks and How' in A. An Na'im (ed) Cultural Transformation and Human Rights in Africa, London: ZED Books.

Cherif, F. (2015) Myths about Women's Rights: How, Where and Why Rights Advance, Oxford, Oxford University Press.

Chinwuba Onuoru-Oguno, A. (2017) 'Protecting Same-sex Rights in Nigeria: Case Note on Teriah Joseph Ebah v.Federal Government of Nigeria' in S. Namwase and A. Jjuko (eds) Protecting the Human Rights of Sexual Minorities in Contemporary Africa, Pretoria: PULP. Chinyere, A.M., Millicent, E. and Elizabeth, A. (2018) 'The Legal, Medical and Social Implications of Early Marriage in Nigeria', International Journal of Law, Policy and the Family 32 (2) 119-39.

Christiansen, L.B. (2009) '“'In our Culture' - How Debates about Zimbabwe's Domestic Violence Law became a "Culture Struggle"”, Nordic Journal of Feminist and Gender Research 17 (2) 175-191.

Connors, J. (2013a) 'Article 28 (on reservations)' in M. Freeman, C. Chinkin and B. Rudolph (eds) The UN Convention on the Elimination of All Forms of Discrimination Against Women A Commentary, Oxford: Oxford University Press 565.

Connors, J. (2013b) 'Optional Protocol' in M. Freeman, C. Chinkin and B. Rudolph (eds) The UN Convention on the Elimination of all Forms of Discrimination against Women: A Commentary, Oxford, Oxford University Press, 608-79.

Cook, R. (1990) 'Reservations to the Convention on the Elimination of all Forms of Discrimination against Women', Virginia Journal of International Law 30, 673-83.

Eekelaar, J. (2013) 'Law and Community Practices' in M. Maclean and J. Eekelaar (eds) Managing Family Justice in Diverse Societies, Oxford, Hart Publishing, 15.

Eekelaar, J. (2010) 'From Multiculturalism to Cultural Voluntarism: A Family Based Approach' The Political Quarterly 10 (2) 344-55. 
El Demery, A. (2015) The Arab Charter of Human Rights: A Voice for Sharia in the Modern World, Council on International Law and Politics. Elias Magoke-Mhoja, M. (2008) Child Widows Silenced and Unheard: Human Rights Sufferers in Tanzania, UK: Authorhouse. Engle-Merry, S., Davies, K. and Kingsbury, B. (2015) Governance by Indicators: Global Power Through Quantification and Rankings, Cambridge: Cambridge University Press.

Engle-Merry, S. (2016) The Seduction of Quantification: Measuring Human Rights, Gender Violence and Sex Trafficking. Chicago: University of Chicago Press.

Engle-Merry, S. (2017) 'The Vernacularisation of Women's Rights' in Hopgood, Snyder and Vijamuri (2017) 213-38.

Ewelukwa, U. (2002) 'Post-Colonialism, Gender, Customary Injustice: Widows in African Societies' Human Rights Quarterly 24 (2) 424-86.

Facio, A. and Morgan, M. (2009) Equity or Equality for Women? Understanding CEDAW's Equality Principles, IWRAW Asia-Pacific, Occasional Papers Series No. 14, Kuala Lumpur, IWRAW.

Goodman, R. and Jinks, D. (2013) Socializing States: Promoting Human Rights Through International Law, Oxford: Oxford University Press.

Himonga, C. (2017) 'Analysis: Mifumi (u) Itd \& others v Attorney General Kenneth Kakuru' at https://africanlii.org/content/analysis-mifumi-u-ltd-others-v-attorney-general-kennethkakuru (last accessed 26 January 2019).

Himonga, C. and Moore, E. (2016) Reform of Customary Marriage, Divorce and Succession in South Africa: Living Customary Law and Social Realities, Cape Town: Juta.

Hopgood, S. (2015) The End times of Human Rights, Ithaca: Cornell University Press.

Hopgood, S., Snyder, J. and Vijamuri L. (eds) (2017) Human Rights Futures, Cambridge: Cambridge University Press.

Human Dignity Trust (2016) Breaking the Silence: Criminalisation of Lesbian and Bisexual Women and its Impact, London: Human Dignity Trust.

Jacobsen, M. and Bruun, ). (2000) Human Rights and Asian values: Contesting National Identities and Cultural Representation in Asia, Abingdon: Routledge. 
Jerven (2013) Poor Numbers: How we are Misled by African Development Statistics and What to Do about It, Ithaca: Cornell University Press, 2013.

Langwenya, M. (2012) 'Historic step towards equality for Swazi women: An analysis of Mary-Joyce Doo Aphane v the Registrar of Deeds', Open Society Initiative for Southern Africa, Open Debate 06, 5.

Mackinnon, C. (2017) Butterfly Politics, Cambridge Mass: Belknap Press.

May, J. Changing People, Changing Laws, Gweru: Mambo Press.

Mayer, A.E. (2013) Islam and Human Rights, New York: Westview.

Morsink, J. (2000) The Universal Declaration of Human Rights: Origins, Drafting and Intent, Philadelphia: University of Pennsylvania Press.

Musawah (2017) CEDAW and Muslim Family Laws, Musawah Building Briefs 04:

http://www.musawah.org/sites/default/files/MusawahPaper_Issue4_English_singlepg.pdf (last accessed 25 January 2019).

Nussbaum, M. (2016) 'Women's Progress and Women's Human Rights', Human Rights Quarterly, 38 (3) 589-622.

Nyamu Musembi, C. (2013) 'Pulling apart? Treatment of pluralism in the CEDAW and the Maputo Protocol' in A. Hellum, and H.S. Aasen, H.S. (eds) (2013) Women's Human Rights: CEDAW in International, Regional and National Law (Studies on Human Rights

Conventions), Cambridge: Cambridge University Press, 183-214.

Posner, E. (2014) The Twilight of Human Rights Law (Inalienable Rights) Oxford: Oxford University Press.

Risse, T., Ropp, S. and Sikkink, K. (eds) (1995) The Power of Human Rights: International Norms and Domestic Change, Cambridge: Cambridge University Press.

Risse, T. (2013) The Persistent Power of Human Rights: From Commitment to Compliance, Cambridge: Cambridge University Press.

Ruppel, O.C. (ed.) (2008) Women and custom in Namibia: Cultural practice versus gender equality? London: Macmillan Education.

Santos, B. de S. (1997) 'Towards a Multicultural Conception of Human Rights' XXIVI Sociolgia del Diritto 27. 
Simmons, B. (2011) Mobilizing for Human Rights: International Law in Domestic Politics, Cambridge: Cambridge University Press.

Sloth Nielsen, J. (2016) 'The Constitutional Court Rules on Child Marriage in Zimbabwe:

"No"' in B. Aitken (ed) International Survey of Family Law 2016 , Bristol, Family Law.

Ssenyonjo, M. (2007) 'Culture and the human rights of women in Africa: Between light \& shadow', Journal of African Law 51 (1) 39 - 67.

Ssenyongo, M. (2008) 'Towards non-discrimination against women and de jure equality in Uganda: the role of Uganda's Constitutional Court' African Journal of International and Comparative Law 16 (1) 1 - 34.

Tsanga, A. (2003) Taking Law to the People: Gender, Law Reform and Community Legal Education in Zimbabwe, Harare: Weaver Press.

Viljoen, F. (2012) International Human Rights Law in Africa, Oxford: Oxford University Press.

\section{NOTES}

\footnotetext{
${ }^{1}$ Convention on the Elimination of all forms of Discrimination against Women (1979) 1249 UNTS 13

${ }^{2}$ Consideration of reports submitted by States parties under article 18 of the Convention on the Elimination of All Forms of Discrimination against Women, Fifth periodic report of States parties, Madagascar,

CEDAW/C/MDG/5, 29 January 2008, para. 110; Consideration of reports submitted by States parties under article 18 of the Convention on the Elimination of All Forms of Discrimination against Women, Combined initial, second, third, fourth, fifth and sixth periodic reports: Guinea-Bissau, CEDAW/C/GNB/6, 30 June 2009, para. 85 .

${ }^{3}$ See CEDAW “Inputs to the 2017 High Level Political Forum on Social Development" at:

file:///C:/Users/fb9/Desktop/CEDAW_HLPF17_28.04.2017.pdf. CEDAW was used extensively in the drafting of indicators especially, Goal five on equality. UN Women, Report of the workshop on SDG Indicator 5.1.1

'Whether or not legal frameworks are in place to promote, enforce and monitor equality and non-discrimination on the basis of sex, Workshop held at UN Women, New York, 14 and 15 June 2016. The Committee also invokes the SDG responsibility of States in its concluding observations. Rwanda, CEDAW/C/RWA/CO/6 paras. 4,43,44; Niger, CEDAW/C/NER/2-3/ (2017) paras. 13,21,25,35,46.

${ }^{4}$ Protocol to the African Charter on the Rights of Women, 2003(2003) OAU AHG/Res. 240; OECD Sahel and West Africa Club 'Gender Equality in West Africa' (2017) at www.oecd.org; Southern African Development Community (SADC) Protocol on Gender and Development, 2008 at: http://www.achpr.org/instruments/sadcgender-development/

${ }^{5}$ African Commission on Human and Peoples' Rights, Ratification Table: Protocol to the African Charter on Human and Peoples' Rights on the Rights of Women in Africa, at: http://www.achpr.org/instruments/womenprotocol/ratification/.
}

${ }^{6} \mathrm{CEDAW} / \mathrm{C} / \mathrm{NGA} / \mathrm{CO} / 6$ (2008), para. 320.

${ }^{7}$ Senegal, CEDAW/C/SEN/CO/3-7, (2015) para.12@. 
${ }^{8}$ It is gratifying to see how often CEDAW is invoked in national jurisdictions: discussed by Bond (2014). For discussions of CEDAW related case law in Nigeria, see Ewelukwa (2002); for Ugandan case law, see Ssenyongo (2008); for Kenya, see Banda (2014).

${ }^{9}$ See also Bond (2014).

${ }^{10}$ See also socio-legal studies undertaken by Tsanga (2003) and Elias Magoke-Mhoja (2008).

11 See also Bond (2014).

12 Posner (2014); Hopgood (2015); Hopgood, Snyder and Vijamuri (eds) (2017).

13 Risse, Ropp and Sikkink (eds) (1995); May (2003); Risse (2013). Through the prism of the concept of honour, and using the work of Keck and Sikkink, philosopher, Anthony Appiah (2010) seeks to identify why some human rights initiatives are more successful than others. A. Appiah The Honour Code: How Moral Revolutions Happen.

${ }^{14}$ See further Simmons (2011).

${ }^{15}$ See Goodman and Jinks (2013); compare Cherif (2015) 161-2.

${ }^{16}$ For a critique of An Na'im see Santos (1997).

${ }^{17}$ Joint CEDAW General Recommendation No. 31 and Committee on the Rights of the Child, General

Comment No.18 on Harmful Practices, CEDAW/C/GC/31-CRC/C/GC/18, para.60. See also paras. 61,66, 81(a).

${ }^{18}$ Make Every Woman Count (MEWC) African Women's Decade 2010-2020 Mid-Term Review (MEWC, 2016) 13.

${ }^{19}$ CEDAW/C/SR.837, 8 August 2008, para.48. See also CEDAW/C/UGA/CO/7, para. 4 and A. Byrnes and M. Freeman (2012) 16 on the importance of civil society and other agencies assisting with report writing and legal change.

${ }^{20} \mathrm{CEDAW} / \mathrm{C} / \mathrm{RWA} / \mathrm{CO} / 7-9$, paras. 8 and 9 .

${ }^{21}$ CEDAW/C/NER/CO/3-4, para. 12 (b).

${ }^{22}$ Sarah Longwe v. Intercontinental Hotels [1993 4 LRC 221; Ephraim v. Pastory [1990] LRC 757;

Mandizvidza v. Chaduka No. and Morgenster College v. The Minister of Higher Education 1992 (2) ZLR 375; Attorney General v. Dow (2001) AHRLR 172. However, see Magaya v. Magaya 1999 (1) ZLR 100. See generally, Viljoen (2012: 518-43).

${ }^{23}$ See Chanock (2002); Jacobsen and Bruun (2000); African Charter, preamble. While reiterating the importance of African values, the African Women's Protocol, in its preamble, links these to 'the crucial role of women in the preservation of African values based on the principles of equality, peace, freedom, dignity, justice, solidarity and democracy.' (Emphasis added). It is important to emphasize that there is not consensus on treaty interpretation. See for example the differences between A. El Demery (2015) and Mayer (2013). In its concluding observations to the report of Mali, CEDAW sought to 'Encourage open and inclusive public debates regarding diversity of interpretation with regard to Muslim family laws and practices, in order to combat justification of discrimination against women in the name of religion.' CEDAW/C/MLI/CO/6-7, para. 44(d).

${ }^{24}$ CEDAW GR 21 para. 13; CEDAW GR 29 paras. 10-17. See also UN Human Rights Committee (HRC), CCPR General Comment No. 19: Article 23 (The Family) Protection of the Family, the Right to Marriage and Equality of the Spouses, 27 July 1990, available at: http://www.refworld.org/docid/45139bd74.html

${ }^{25}$ Constitution of the Republic of South Africa, 1996 s. 9(3); South Africa, Civil Union Act [Act 17] 2006.

However, South Africa has been censured for violence against lesbian women by the CEDAW Committee. See CEDAW/C/ZAF/CO/4 (2011) para.SUPPLY NUMBER

${ }^{26}$ Arab Charter, 2004 reprinted in 12 Int'l Hum. Rts. Rep. 893 (2005) art. 33(1); Constitution of Kenya, 2010 art 45b (2), Constitution of Zimbabwe, 2013, s. 78 (3).

${ }^{27}$ Nigeria, Same Sex Marriage (Prohibition)Act, 2014

${ }^{28}$ Human Rights Committee General Comment No. 18 on Discrimination, UN Doc. 10/11/89 (1989). CEDAW General Recommendation No. 28 on State Obligations.

${ }^{29}$ CEDAW General Recommendation No 28 on the Core Obligations of States Parties under art 2 of the Convention, CEDAW/C/GC/28 (16 December 2010). CESCR General Comment No. 20 on Discrimination, Human Rights Committee General Comment No. 28 on article 3 on Equality Between Men and Women CEDAW General Recommendation No. 25 on Temporary Special Measures, CEDAW GR 28. See also Concluding Observations of the Committee on Economic, Social and Cultural Rights, Democratic Republic of the Congo, E/C.12/COD/CO/4, 20 November 2009, para. 20. For a consideration of equality norms in family human rights, see Banda and Eekelaar (2017). 
${ }^{30}$ Inter-American Court Advisory Opinion OC 18/03, 17 September 2003, Inter-Am Ct HR (Ser. A) No. 18, 2003, paras 82-110. Communication No. 323/2006 Egyptian Personal Rights Project and Interights v. Egypt. Both cases reference CEDAW on discrimination.

${ }^{31}$ Cairo Declaration on Human Rights in Islam Aug. 5, 1990, U.N. GAOR, World Conf. on Hum. Rts., 4th Sess., Agenda Item 5, U.N. Doc. A/CONF.157/PC/62/Add.18 (1993)

${ }^{32}$ CEDAW General Recommendation No. 25 on Temporary Special Measures UN Doc. HRI/GEN/1/Rev.9 (Vol. 11) para. 8. See also CEDAW General Recommendation No. 28 on The Core Obligations of States Parties, UN Doc. CEDAW/C/GC/28.

${ }^{33}$ Saudi Arabia, CEDAW/C/SAU/2 (2007) at 11. This view reflects article 6 of the Cairo Declaration.

${ }^{34}$ Egypt has entered a reservation to article 18(3) of the African Charter. Thirty-Seventh Ordinary Session 27 April - 11 May 2005, Banjul, The Gambia, Consideration of Reports submitted by States Parties under the Terms of Article 62 of the African Charter on Human and Peoples' Rights Concluding Observations and Recommendations on the Seventh and Eighth Periodic Report of the Arab Republic of Egypt, paras. 1 and 25 where the Commission asks the State to withdrawn its reservation to article 18(3). Egypt has however withdrawn its reservation to article 21 of the African Charter on the Rights and Welfare of the Child on early marriage.

${ }^{35}$ As of October 24, forty African States had ratified the Maputo Protocol with South Sudan ratifying in October 2017.

36. It is noteworthy that CEDAW's persistent calls for rationalisation of national laws fall on deaf ears. Sierra Leone, CEDAW/C/SLE/CO/5, paras.38,39. CEDAW/C/SLE/CO/5

${ }^{37}$ See the Indian Supreme Court in Danial Latifi v. Union of India (2001) SC 3958 (AIR).

${ }^{38}$ Communication No. 323/2006 Egyptian Personal Rights Project and Others v. Interights, paras. 87-90.

${ }^{39}$ Communication No. 323/2006, paras. 121-123. The Commission also referred to the equality clause in the Egyptian constitution-para. 127 and the Human Rights Committee case law on testing for discrimination-paras. 146-7. In its concluding observations to its sixth report to CEDAW Nigeria cited six cases on the dissolution of marriages due to lack of consent and also violence, inheritance rights of daughters and custody of children. The Nigerian government was clearly of the view that there had been a permeation of the importance of protecting women and girls from abuse, including in the family. It cited article 18(3) of the African Charter.

CEDAW/C/NGA/6, para. 1.4.2

${ }^{40}$ Communication No. $323 / 2006$ paras. $123,158-165$.

${ }^{41}$ See for example, the manual drafted by Equality Now to aid strategic litigation. Equality Now, A Guide to Using the Protocol on the Rights of Women in Africa for Legal Action, Equality Now, 2011.

${ }^{42}$ Dorothy Njemanze and 3 others $v$ The Federal Republic of Nigeria, ECOWAS suit ECW/CJ/APP/17/14, judgment delivered, 12 October 2017. IHRDA "ECOWAS Court makes first pronouncement on Maputo Protocol: Rules in favour of plaintiffs in case of Dorothy Njemanze \& 3 Ors V Federal Republic of Nigeria" Banjul, 12 October 2017, at: http://www.ihrda.org/2017/10/ecowas-court-makes-first-pronouncement-onmaputo-protocol-rules-in-favour-of-plaintiffs-in-case-of-dorothy-njemanze-3-ors-v-federal-republic-ofnigeria/. (last accessed 25 January 2019).

${ }^{43}$ The CEDAW position has evolved over time-from General Recommendation No. 21, via General Recommendation No. 27 on older women, to General Recommendation No. 29 on Property Consequences to General Recommendation No. 34 on rural women. Discussed in Banda and Eekelaar (2017).

${ }^{44}$ Uganda, CEDAW/C/UGA/CO/7 paras. 11 and 12.

${ }^{45}$ Report of the Special Rapporteur in the field of cultural rights, Karima Bennoune A/72/155 (2017), para.6.

${ }^{46} \mathrm{CEDAW} / \mathrm{C} / \mathrm{NER} / \mathrm{CO} / 3-4$ para. 9 (a).

${ }^{47}$ CEDAW GR 21 para. 45.

${ }^{48}$ CEDAW GR 20 on Reservations UN Doc HRI/GEN/1/Rev.9(Vol II); CEDAW GR 21 on family paras. 44, 46, 47-49. Connors (2013: 581).

${ }^{49}$ Niger Reservation to article 5-CEDAW at: http://www.un.org/womenwatch/daw/cedaw/reservationscountry.htm

${ }^{50}$ UN Working Group on Laws and Practices that Discriminate against Women, A/HRC/29/40 (June 2015) para 23: See also Concluding observations of the Committee on Economic, Social and Cultural Rights, BENIN, E/C.12/BEN/CO/2, 9 June 2008, para. 14; Concluding observations of the Committee on Economic, Social and Cultural Rights, MOROCCO, E/C.12/MAR/CO/3, 4 September 2006, para. 10.

${ }^{51} \mathrm{He}$ also discusses cultural voluntarism in. Eekelaar (2010). See CEDAW General Recommendation No. 21 paras. 44 and 50 . 


\footnotetext{
${ }^{52}$ BBC "1960.Macmillan Speaks of Wind of Change in Africa” BBC, London, 3 February 1960 Available at: http://news.bbc.co.uk/onthisday/hi/dates/stories/february/3/newsid_2714000/2714525.stm

${ }^{53}$ Sierra Leone, CEDAW/C/SLE/CO/5, paras.12,13

${ }^{54}$ Uganda, 1995, art. 21; Ghana, 1992, s.17 and 22 on equality in marriage; South Africa, 1996 s. 9(3); Nigeria, 1999, s.42; Swaziland, 2005, ss.20 and 28. Kenya, 2010 art.27, Tanzania, Article 13 (1), Article 13 (5) and article 13 (2), which states that 'no law enacted by any authority in the United Republic shall make any provision that is discriminatory either of itself or in effect', article 29 (2), according to which 'every person in the United Republic has the right to equal protection under the laws': Constitution of the Republic of Zimbabwe Amendment (No. 20) 2013 s. 80.

${ }^{55}$ ES and SC (Represented by the Women's Legal Aid Centre and the International Women's Human Rights Clinic v. Tanzania, CEDAW/C/60/D/48/2013, 2 March 2015, para. 7.6; Uganda, CEDAW/C/UGA/CO/7 para.12.

${ }^{56}$ Sierra Leone, CEDAW/C/SLE/CO/5, paras.21,22; Uganda, CEDAW/C/CO/7, pars 19, 20. Mali, CEDAW/C/MLI/CO/6-7, paras.11, 43,44.
}

${ }^{57} \mathrm{CEDAW} / \mathrm{C} / \mathrm{UGA} / \mathrm{CO} / 7$, paras. 41 and 42 . The resolution of this conundrum-reconciling practice with gender equality has been, and is likely to remain the issue of concern to women and policy makers. See Ruppel (2008); Himonga and Moore (2016); Ssenyonjo (2007).

${ }^{58}$ Application No. 79/14, Judgment No. CCZ 12/2015 (henceforth Mudzuru).

${ }^{59}$ See Applicant's Heads of Argument in In the matter between Loveness Mudzuru \& Another v Minister of Justice Legal \& Parliamentary Affairs \& 2 Others Case Number CCZ 79/2014 Prepared by Tendai Biti Law, 1 December 2014. Marriage Act [Chapter 5:11]; Customary Marriages Act [Chapter 5:07].

${ }^{60}$ Applicant's Heads of Argument, 2014, paras. 83 and 85

${ }^{61}$ Ibid, paras. 96, 102. They also cited section 80 on the rights of women. Interestingly, this 'early maturation of girls' argument was run, unsuccessfully in another CEDAW (article 5) related case on education in Hong Kong (girls were getting access to the best high schools because their better test results reflected their early advantage): Equal Opportunities Commission v. Director of Education HCLA 1555/2000 reported in 2001 HKLRD 690. I remain grateful to Andrew Byrnes for alerting me to this case.

${ }^{62}$ Applicant's Heads of Argument, 2014, para. 125.

${ }^{63}$ Ibid, paras. 124 and 125.

${ }^{64}$ Mudzuru,.27-30.

${ }^{65}$ Ibid, 27, 31-32

${ }^{66}$ Ibid, 32

${ }^{67}$ African Charter on the Rights and Welfare of the Child, 1990 art. 21. Mudzuru, 35

${ }^{68}$ Mudzuru, 39-41.

${ }^{69}$ Ibid, 37,38 .

${ }^{70}$ See for example, Commonwealth Secretariat Victoria Falls Principles for Promoting the Human Rights of Women, reproduced in Byrnes et al (eds) (1994)

${ }^{71}$ The Dow case challenged discriminatory nationality laws while the Sarah Longwe cases successfully challenged limits put on women's freedom of movement which led to their being banned from entering the Intercontinental Hotel in Lusaka, Zambia, unless accompanied by a man. Both invoked human rights norms. Attorney-General v. Dow 1992 LRC (Const) 623; Longwe v. Intercontinental Hotels [1993] 4 LRC 221. Dow has been extensively discussed including by Bond (2014) and also by Cherif (2015) who starts her book with the case. See also Nussbaum (2016).

${ }^{72}$ Plan Because I am a Girl; Girls not Brides at: https://www.girlsnotbrides.org/resource-centre/state-of-theworlds-girls-creating-sustainable-change-for-adolescent-girls/plan-because-i-am-a-girl/ (last accessed 25 January 2019); Joint CRC General Comment No. 18 and CEDAW General Recommendation 31on Harmful Practices, CEDAW/C/GC/31-CRC/C/GC/18 (2014); UNICEF, Ending Child Marriage: Progress and prospects (UNICEF, 2014); African Union Campaign to End Child Marriage at: https://au.int/en/sa/cecm; UN General Assembly Resolution on Child, Early and Forced Marriage, UNGA 71/175, 23 January 2017.

${ }^{73}$ However, the headline to the piece by Ismail Akwei, tells a different story with respect to the practice of states 'Tanzania - The Attorney General Has Appealed Against a July 2016 Ruling by the High Court Which Raised the Marriage Age for Girls from 15 to 18 - In Africa, 40\% of Girls Marry Before Age 18':

http://www.africanews.com/2017/09/29/tanzania-s-ag-appeals-against-court-ruling-raising-marriage-age-forgirls-to-18/ (29 September 2017). Akwei also notes how the Zimbabwean government had not as yet, passed a law to reflect a Supreme Court judgement which ruled that the Marriage Act which permitted marriage at 16 was in breach of the Constitution which set 18 as the minimum age of marriage: see Sloth Nielsen (2016). 
${ }^{74}$ The Attorney-General v. Mary-Joyce Doo Aphane, (2010) SZSC 32 (henceforth Mary Doo Aphane (SC)) para.4. See also para. 25 .

${ }^{75}$ Mary Doo Aphane para. 7 (SC)

${ }^{76}$ Ibid, para. 8 (SC)

${ }^{77}$ Of particular note here is section 28(3): 'A woman shall not be compelled to undergo or uphold any custom to which she is in conscience opposed.'

${ }^{78}$ Mary Joyce Doo Aphane v. Registrar of Deeds and the Minister of Justice and Constitutional Affairs, CIVIL CASE NO. 383/2009 (HC)

${ }^{79}$ Mary Doo Aphane paras. 27-34 (SC)

${ }^{80}$ Ibid, para. 60 (SC). See also Langwenya (2012: 5); Cherif (2015: 144-5,162-3,165-6).

${ }^{81}$ The Court went into some detail on the issue of surnames and surveyed the social and legal history behind women changing their surnames on marriage. It came down firmly in favour of Aphane's right to retain the name of her birth. Doo Aphane paras. 13-18 (SC).

${ }^{82}$ Mary Doo Aphane para. 70 (SC).

${ }^{83}$ Ibid,, paras. 68 and 69 (SC). See also CEDAW General Recommendation No. 33 on Access to Justice.

${ }^{84}$ Cherif (2015: 166) is clear that culture and norm-building are important factors in understanding women's property rights in developing countries, but notes that as explanations for change or the lack thereof 'they are both overstated and incomplete'.

${ }^{85} \mathrm{CEDAW} / \mathrm{C} / \mathrm{SWZ} / \mathrm{CO} / 1-2$, 24 July 2014, para.8.

${ }^{86} \mathrm{CEDAW/C/SWZ/CO/1-2/Add.1,21} \mathrm{April} \mathrm{2017,} \mathrm{para.} 2$

${ }^{87}$ Mifumi (U) Ltd \& 12 Others v Attorney General, Kenneth Kakuru (Constitutional Appeal No. 02 of 2014) [2015] UGSC 13 (6 August 2015) (henceforth Mifumi). See also Mujuzi (2019).

${ }^{88} \mathrm{CEDAW} / \mathrm{C} / \mathrm{UGA} / \mathrm{CO} / 7$, paras. 20 and 47.

${ }^{89}$ Constitution of Uganda, 1995 art. 21.

${ }^{90}$ Article 32(2) of the Constitution states: 'Laws, cultures, customs and traditions which are against the dignity, welfare or interest of women or any marginalized group to which clause (1) relates or which undermine their status, are prohibited by this Constitution'.

${ }^{91}$ African Women's Protocol art. 3.

${ }^{92}$ Article 31(1) provides that: 'men and women of the age of eighteen and above have the right to marry and to found a family and are entitled to equal rights in marriage, during marriage and at its dissolution '.

${ }^{93}$ UN Special Rapporteur in the Field of Cultural Rights, Farida Shaheed, Report on the Cultural Rights of Women, A/67/287, 10 August, 2012.

${ }^{94}$ Optional Protocol on the Convention on the Elimination of all Forms of Discrimination against Women, 1999 , 2131 UNTS 237.

${ }^{95}$ ES and SC (Represented by the Women's Legal Aid Centre and the International Women's Human Rights Clinic v. Tanzania, CEDAW/C/60/D/48/2013, 2 March 2015 (henceforth ES and SC v Tanzania)

${ }^{96}$ ES and SC v. Tanzania, para. 3.1.9 and 8. For the Committee's reading see paras. 7.2 to 7.9 .

${ }^{97}$ Ibid, , para. 7.

${ }^{98}$ CEDAW General Recommendation No. 29 para. 53 cited in ES and SC v Tanzania, para. 7:2

${ }^{99}$ ES and SC v. Tanzania, para. 9) b) (v). Here CEDAW seems to be able to apply the modify part of article 2(f) rather than simply focusing on abolition. Article 2(f) enjoins States "to take all appropriate measures, including legislation, to modify or abolish existing laws, regulations, customs and practices which constitute discrimination against women."

${ }^{100}$ ES and SC v. Tanzania, para. 9 (b)(iv) and (vi).

${ }^{101}$ The issue of improving legal literacy and access to justice, elaborated upon in General Recommendation No. 33 on Access to Justice, looms large in CEDAW engagement with States. DRC, CEDAW/C/COD/CO/5, para.12; Mali, CEDAW/C/MLI/CO/6-7, paras.13,14; Senegal, CEDAW/C/CO/3-7, para.12; Liberia, CEDAW/C/LBR/CO/7-8, paras. 14(b), 14(c),16. 
${ }^{102}$ Concluding observations (2016) CEDAW/C/TZA/CO/7-8, para. 50

${ }^{103}$ Ibid, paras 9 and 50.

${ }^{104}$ (CEDAW/C/RWA/6, CEDAW/C/RWA/Q/6 and Add.1, Para, 43.

${ }^{105}$ Ibid para para.22 Also worth mentioning is the impact of post-conflict peace initiatives, not least UN

Security Council Resolution 1325 on women, peace and security and its successor resolutions. In General

Recommendation 30 on women in armed conflict the Committee focuses on the importance of preventing forced marriage as this conflicts with articles 16(1)(a) and 16(1)(b) on the same rights to enter into marri age. It also highlights the disproportionate impact on women headed households of a lack of access to economic

opportunities and links this to article 16(1) (h). It reinforces the obligations of States to adopt gender sensitive policies on inheritance law. ${ }^{105}$ The normative impact of the insistence on gender equality being central to peace agreements and the reconstruction of the legal order which follows conflict are easy to trace. Rwanda is the exemplar of post conflict change. See for example, the question and answer session with Rwanda marking changes to laws and policies post genocide, combined fourth to sixth periodic report of Rwanda (CEDAW/C/RWA/6, CEDAW/C/RWA/Q/6 and Add.1), paras 3,7,16,20

${ }^{106} \mathrm{CEDAW} / \mathrm{C} / \mathrm{SLE} / \mathrm{CO} / 5$, (2007) paras. 6,14, 26,27 